[Case Report]

\title{
Keratocystic Odontogenic Tumor Invading the Maxillary Sinus: A Case Report of Collaborative Surgery Between an Oral Surgeon and an Otorhinolaryngologist
}

\author{
Takanobu Kunihiro $^{1 *}$, Hiromasa KawAnA ${ }^{2}$, Rie KodaKA ${ }^{2}$ and Toshihiko OBA ${ }^{3}$ \\ ${ }^{1}$ Department of Otolaryngology Head-Neck Surgery, School of Medicine, Keio University, Shinjuku-ku, Tokyo 160- \\ 8582, Japan \\ ${ }^{2}$ Department of Dentistry and Oral Surgery, School of Medicine, Keio University, Shinjuku-ku, Tokyo 160-8582, Japan \\ ${ }^{3}$ Keiyu Ginza Clinic, Chuo-ku, Tokyo 104-0045, Japan
}

\begin{abstract}
We report a case of keratocystic odontogenic tumor (KCOT) in a 21-year-old female patient. The patient was referred to our clinic from a dental clinic for the radical treatment of recurrent KCOT in the maxilla. She had undergone conservative drainage surgery twice at that clinic. The tumor was cystic and covered with a bony capsule, which extended high into the maxillary sinus. A pinhole fistula, which was created during a previous surgery, was identified in the gingivobuccal sulcus. The whole tumor was successfully removed using a bidirectional approach from the fistula and from the antrostomy in the middle meatus. This report shows that the intimate collaboration between an otorhinolaryngologist and an oral surgeon could provide a minimally invasive, and at the same time, radical surgical treatment for certain kinds of tumor in the head and neck region. We also recommend the introduction of endoscopic surgeries by the oral surgeon.
\end{abstract}

Keywords : KCOT, maxillary sinus, endoscopic surgery, oral surgeon, otorhinolaryngologist.

(Received November 22, 2013, accepted October 29, 2014)

\section{Introduction}

Keratocystic odontogenic tumor (KCOT) is the second most frequent type of tumor in children and adolescents, accounting for one-fourth of all odontogenic tumors [1]. This tumor shows an aggressive clinical behavior, including a high recurrence rate, and demonstrates a high mitotic count and high epithelial turnover rate [2]. Because of these neoplastic features, the formerly used term "odontogenic keratocyst" was changed to "keratocystic odontogenic tumor" in the WHO classification of head and neck tumors in 2005 $[2,3]$.

The radiological features of KCOT are not pathog- nomonic. In $25-40 \%$ of cases an unerupted tooth is involved, which results in the clinico-radiological diagnosis of a dentigerous cyst. Other different diagnoses may include ameloblastoma, radicular cyst, simple bone cyst, central giant cell granuloma, arteriovenous malformation, and a number of fibro-osseous lesions [4-6].

The most conservative surgical treatment of KCOT is enucleation with or without the use of adjunctive treatment. However, this treatment often results in recurrence of up to $56 \%$, as opposed to resection, after which no recurrence has been reported [6].

This paper reports a case of a recurrent keratocystic odontogenic tumor in the posterior maxilla. Our surgi-

*Corresponding Author: Takanobu KunihIRo, MD, Department of Otolaryngology Head-Neck Surgery, School of Medicine, Keio University. 35 Shinanomachi, Shinjuku-ku, Tokyo 160-8582, Japan, Tel: +81-3-5363-3827, Fax: +81-3-3353-1261, Email: takanobu@kunihiro.name 
cal team (oral surgeon and otorhinolaryngologist) was able to totally resect the tumor invading the maxillary sinus by a combination of intraoral and endoscopic endonasal approaches. Although the first molar, the root of which was invaded by the tumor, was extracted, other vital anatomical structures were preserved with minimal morbidity. We advocate a close collaboration between the oral surgeon and otorhinolaryngologist in the surgical treatment of intraoral and peri-oral lesions.

\section{Case Report}

In August, 2012, a 21-year-old female patient was referred to the senior author's outpatient clinic by an oral surgeon at a local university hospital, seeking treatment of a recurrent keratocystic odontogenic tumor (KCOT) in the right maxilla. In 2006, the patient had undergone initial surgery consisting of the extraction of the impacted second molar and drainage of the cyst, based on an initial diagnosis of a dentigenous cyst. However, the pathological diagnosis was "keratotic odontogenic tumor with massive infiltration of plasma cells". The patient underwent a second surgery to partially resect the tumor in 2010 (Fig. 1). Radical resection was not performed to preserve the functionally and cosmetically important structures adjacent to the tumor and to avoid facial and intraoral deformity (details are not known).

At her presentation to the senior author's otolaryngology clinic, the patient complained of a right-side

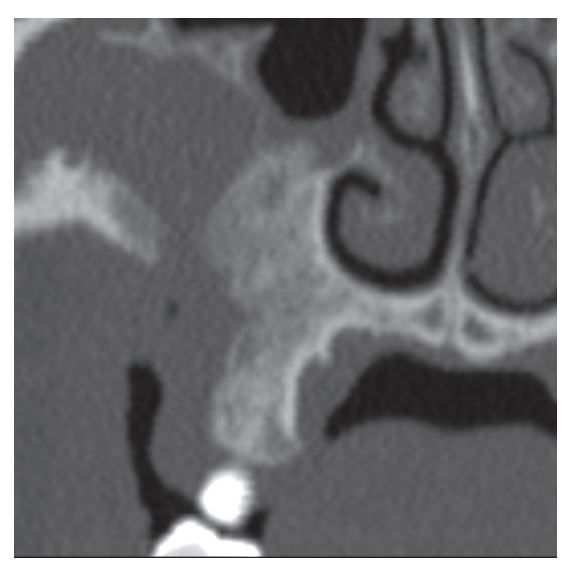

Fig. 1. CT seven months after the second surgery at a local university hospital. The opening of the fistula (drainage pathway) can be identified. Its lumen is partially aerated. nasal obstruction and post-nasal drip. Medical examination revealed a pin-hole fistula in the gingivobuccal sulcus on the right side. No swelling of the gingiva or the cheek was noted. Nasal endoscopy revealed a purulent discharge from the middle meatus on the right side. Computed tomography (CT) showed a large cystic lesion occupying the inferior and lateral portion of the right maxillary sinus. A remnant of a tooth was also identified (Fig. 2A). Another CT image showed an invasion of the tumor into one of the roots (posterior buccal root) of the first molar (Fig. 2B).

Surgery was started by the oral surgeon (HK). First, a wedge-shaped incision surrounding the fistula was made in the gingivobuccal sulcus; the incision was extended anteriorly to the first molar in order to obtain a larger visual field. Enucleation was performed along the bony wall of the fistula (maxillary alveolar ridge) and then along the inside surface of the bony capsule protruding into the maxillary sinus. The otorhinolaryngologist (TK) visualized the operation field with an endoscope while HK peeled off the soft tissue from the dome-shaped, partially lobulated bony wall through a tiny hole (bone defect) at the site of the incision (original fistula site). After resecting the whole soft tissue, the bone tissue surrounding the fistula (the site of the initial incision) was drilled off, again with the aid of the endoscope. This enabled close inspection of one of the roots of the first molar, which confirmed the preoperative finding on the CT that the tumor had invaded the buccal posterior root of the first molar. Consequently, the first molar was extracted.

The 'de-epithelized' bony wall, which was still separating the 'tumor' space from the original maxillary sinus cavity, had to be removed to assure total resection of the tumor and drain the 'tumor' space from the original maxillary sinus. However, penetrating the bony wall from the 'tumor' side was dangerous because it might injure the floor of the orbit and the infraorbital nerve behind the wall. Therefore, TK enlarged the natural ostium of the maxillary sinus endoscopically from the nasal side, and through that enlarged ostium penetrated the bony capsule (Fig. 2C). The bony wall was thin and was fractured easily with an L-shaped metal suction tube, enabling HK to identify the floor of the orbit through the hole from the oral cavity. Again visualizing the operating field with the endoscope held 
by TK, the bony wall was almost completely resected with a rongeur by HK from the oral side. The remaining bony wall, thick and attached firmly to the lateral wall of the maxillary sinus, was also subtotally drilled off (this process also required the aid of the endoscope). The original fistula at the initial incision was packed with the rotated flap of the buccal fat tissue, and then the gingiva was sutured.
The postoperative course was uneventful. Pathological diagnosis of the specimen taken around the incision site confirmed the previous diagnosis of keratocystic odontogenic tumor (KCOT) (Fig. 3A, 3B). Six months after surgery, the fistula is now closed completely and aeration of the maxillary sinus has been preserved (Fig. 4A, 4B). Although the follow-up period is still short, no evidence of recurrence has been observed.
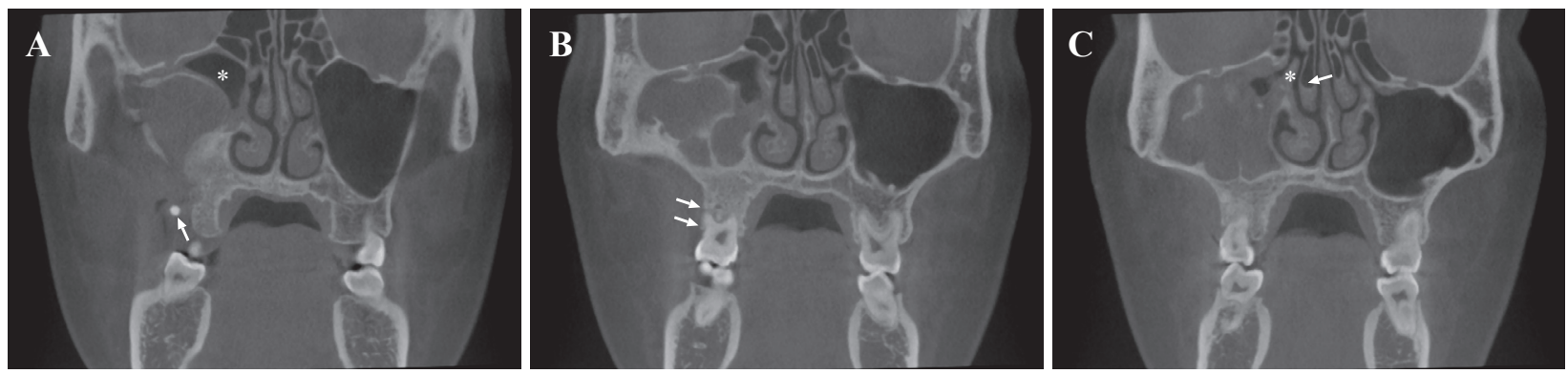

Fig. 2. CT at the time of presentation to the senior author's clinic. A. Intracystic space is filled with soft tissue. The original maxillary sinus cavity is markedly squashed upwards (*). A remnant of the tooth can also be seen (Fig. 2A). B. Tumor invades the periradicular area of the first molar (Fig. 2B). C. To enlarge the natural ostium, the uncinate process $(*)$ was resected. The lateral lamella of the concha bullosa (middle turbinate) (Fig. 2C) was resected to secure the drainage pathway. The ethmoidal bulla was left intact.
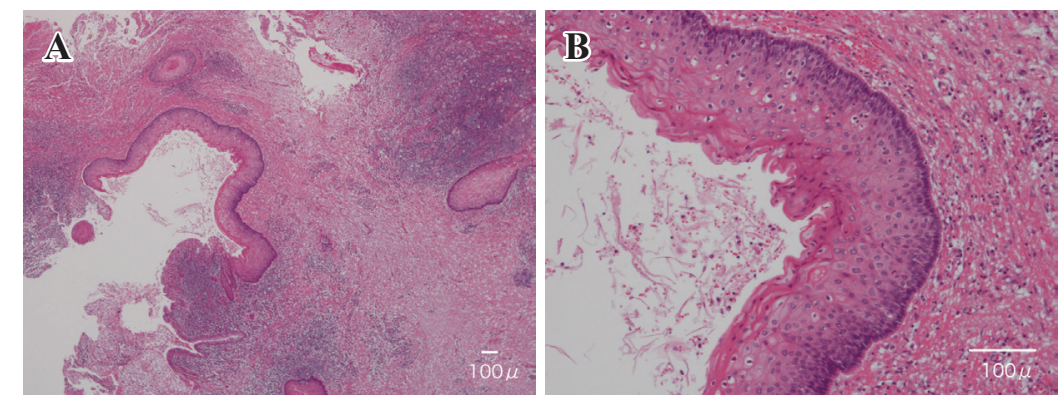

Fig. 3. Typical histological features of keratocystic odontogenic tumor depicted in a combined low power view (Fig. 3A) and high power view (Fig. 3B). Focal infiltration of plasma cells can be observed, indicating the presence of inflammation.
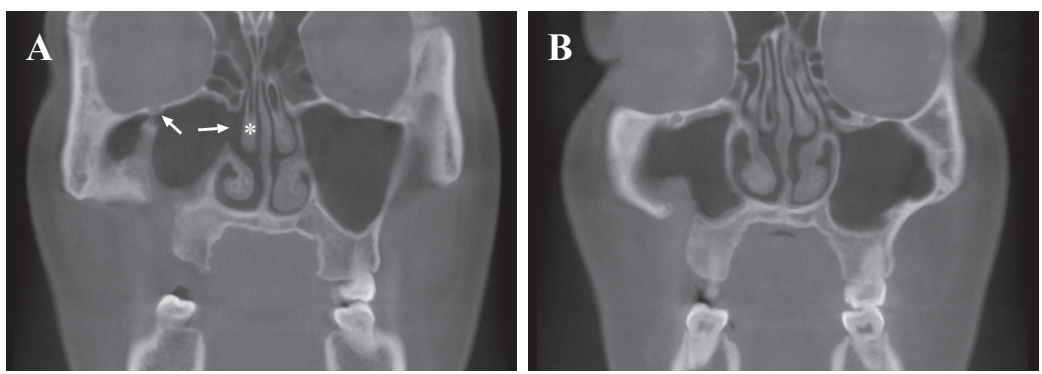

Fig. 4. CT four months after surgery at the senior author's clinic. A. The drainage pathway formed at the site of the natural ostium is wide open (Fig. 4A). The aeration of the lower portion of the middle tubinate is lost $(*)$. Although a small fragment of the bony capsule adhering to the infraorbital nerve still remains, the maxillary sinus is expanded. The lateral portion of the maxillary sinus is also aerated. B. Another slice. Aeration of the maxillary sinus is preserved. 


\section{Discussion}

We report this case to advocate collaborative surgery between the oral surgeon and the otorhinolaryngologist in treating intra- and para-oral tumors to achieve total tumor resection while preserving with minimal morbidity the functionally and cosmetically vital structures.

The most common site for a keratocystic odontogenic tumor (KCOT) is the mandibular molar region [7]. While the most common location is the posterior portion of the mandible or the mandibular ramus, unusual locations have also been reported, such as the anterior portion of the maxilla, the maxillary sinus, and the maxillary third molar area $[8,9]$. KCOT occurs most frequently in the second and third decades of life [7]. Therapeutic approaches vary in different studies, from marspialization and enucleation, which may be combined with adjuvant therapy such as cryotherapy or Carnoy's solution, to marginal or radical resection. The recurrence rate varies from approximately $20 \%$ to $62 \%$. Successful treatment depends on precise diagnosis, adequate surgical procedure, and thorough follow-up $[2,8]$.

Rather conservative surgical treatments (partial resection of tumor and drainage) had initially been performed on our patient. In view of the patient's age (14 years old) at the time of the initial surgical treatment, radical treatment, such as segmental resection of the maxilla, would have produced marked deformity of the face and alveolar bone and functional deficits. However, the invasive characteristic of KCOT as well as the findings from the computed tomography (CT) encouraged us to carry out a radical treatment promptly.

The CT images showed that the first molar was involved in the tumor and therefore it had to be extracted. We decided we would perform dental implantation later on this site if no sign of recurrence were observed for several years. To achieve this, we had to leave as much intact alveolar bone tissue around the first molar as possible. On the other hand, we also had to take into account the possibility that, although not apparent macroscopically, tumor cells might have disseminated around the fistula, which had been formed in previous surgeries to drain the cystic portion of the tumor. Therefore it was considered necessary to remove some of the soft tissues around the fistula (gingiva and buccal mucosa) as long as we could still approximate and suture the wound at the end of the surgery.

These preoperative considerations obliged us to perform a radical tumor resection under highly restricted visual and operation fields, as described above. While the oral surgeon (HK) was performing the operation, the senior author (TK, otorhinolaryngologist) almost always visualized the operation field with the endoscope. In addition, the senior author also enlarged the natural ostium of the maxillary sinus endoscopically, and through it penetrated the bony capsule of the tumor, which allowed drainage of the tumor cavity to the nasal cavity (through the original maxillary sinus). Penetrating the bony capsule from inside the tumor could have injured the orbital floor and the infraorbital nerve.

In spite of general belief, enlarging the natural ostium of the maxillary sinus is not an easy task. It requires years of experience and training and a good understanding of the clinical anatomy of this region. Otherwise, damage to the nasolacrimal duct and/or the orbital content can easily occur.

In our patient, the agger nasi cells in the upper portion of the unciate process and the ethmoidal bulla behind the natural ostium were left intact. Therefore, the enlarged ostium was triangular in shape, bordered by the nasolacrimal duct anteriorly, by the attachment of the inferior turbinate inferiorly, and by the anterior border of the ethmoidal bulla superio-posteriorly. This enlarged natural ostium was large enough to visualize the whole bony wall (covered with maxillary mucosa) and to allow surgical manipulation of it.

Although the follow-up period is still short, we are sure that the tumor was resected totally. According to Stoelinga, there are no studies or even case reports which support the presence of microcysts in the bone surrounding the KCOT $[6,10]$. He reported that studies on recurrent keratocysts have shown that in almost all cases epithelial islands and/or microcysts are present only in the overlying, attached mucosa $[6,10]$.

In conclusion, as the present case shows, collaboration between the oral surgeon and the otorhinolaryngologist is often indispensable to perform a functional and cosmetic surgery in the oral and peri-oral areas. Their collaboration is particularly useful for the sur- 
gical treatment of an extensive tumor in the alveolar process of the maxilla. The excellent visual field of the maxillary floor through the enlarged maxillary sinus osmium enables a more radical but secure per-oral approach by the oral surgeon.

\section{Conflict of Interest}

The authors declare that they have no conflicting interests.

\section{References}

1. Servato JP, de Souza PE, Horta MC, Ribeiro DC, de Aguiar MC, de Faria PR, Cardoso SV \& Loyola AM (2012): Odontogenic tumours in children and adolescents: a collaborative study of 431 cases. Int J Oral Maxillofac Surg 41: 768-773

2. Cakur B, Miloglu O, Yolcu U, Goregen M\&Gursan N (2008): Keratocystic odontogenic tumor invading the right maxillary sinus: a case report. J Oral Sci 50: $345^{-}$ 349

3. Philipsen HP \& Reichart PA (2006): Classification of odontogenic tumours. A historical review. J Oral Pathol
Med 35: 525-529

4. Garlock JA, Pringle GA \& Hicks ML (1998): The odontogenic keratocyst: a potential endodontic misdiagnosis. Oral Surg Oral Med Oral Pathol Oral Radiol Endod 85: 452-456

5. Meara JG, Shah S, Li KK \& Cunningham MJ (1998): The odontogenic keratocyst: a 20-year clinicopathologic review. Laryngoscope 108: 280-283

6. Mendes RA, Carvalho JF \& van der Waal I (2010): Characterization and management of the keratocystic odontogenic tumor in relation to its histopathological and biological features. Oral Oncol 46: 219-225

7. Chirapathomsakul D, Sastravaha P \& Jansisyanont $P$ (2006): A review of odontogenic keratocysts and the behavior of recurrences. Oral Surg Oral Med Oral Pathol Oral Radiol Endod 101: 5-9

8. Brannon RB (1976): The odontogenic keratocyst. A clinicopathologic study of 312 cases. Part I. Clinical features. Oral Surg Oral Med Oral Pathol 42: 54-72

9. MacDonald-Jankowski DS (1992): The involvement of the maxillary antrum by odontogenic keratocysts. Clin Radiol 45: 31-33

10. Stoelinga PJ (1973): Recurrences and multiplicity of cysts. Trans Int Conf Oral Surg 4: 77-80 
上顎洞角化囊胞性歯原性腫瘍一口腔外科と耳鼻咽喉科の合同手術を行った 1 例

國弘 幸伸 ${ }^{1}$, 川奈 裕正 $^{2}$, 小高 利絵 $^{2}$, 大場 俊彦 ${ }^{3}$

${ }^{1}$ 慶應義塾大学 医学部 耳鼻咽喉科頭頸部外科学教室

2 慶應義塾大学 医学部 歯科口腔外科学教室

3慶友銀座クリニック

要旨：上顎洞角化囊胞性歯原性腫瘍 (KCOT) の 1 例を報告する。患者は 21 歳女性. 再発性の KCOT の治療を 他院から依頼された。当科受診時, 患者は既に保存的なドレナージ手術を 2 回受けていた。腫瘍は右上顎第 2 大臼歯 由来であり, CTでは上顎洞内に大きく囊胞様に突出し骨壁に包まれていた。過去の手術時に設けた小さな掼孔が歯 肉煩粘性移行部に確認された。その瘦孔を取り囲むように楔形の切開を加え, 内視鏡を囊胞内に挿入して明視下に 腫瘍の剥離を進めた，骨壁を残して腫瘍を切除した，右上顎第 1 大臼歯の歯根への腫瘍浸潤が認められたため, 右上 顎第 1 大臼歯は抜歯した，骨性の殼を口腔内から破砕すると眼窩底を損傷する可能性があったため, 鼻内から内視鏡 下に上顎洞自然孔を開大し, 開大した上顎洞自然孔側から腫瘍の骨壁を破砕した。その上で, 再度, 瘻孔部から内視 鏡を扦入し, 骨鉗子およびドリルを用いて可及的に骨壁を切除した。術中, 腫瘍は全摘できたと判断した。㾇孔を縫 合閉鎖し，鼻内に止血用ガーゼを挿入して手術を終えた。本症例は，口腔外科領域での手術への内視鏡導入の有用性 を示すとともに, 口腔外科医と耳鼻咽喉科医との合同手術の必要性を示すモデルケースであると考えられた。

キーワード : 角化囊胞性歯原性腫瘍, 上顎洞, 内視鏡手術, 口腔外科医, 耳鼻咽喉科医. 